\title{
Cellulase Production from Species of Fungi and Bacteria from Agricultural Wastes and Its Utilization in Industry: A Review
}

\author{
Muhammad Imran ${ }^{1,2 *}$, Zahid Anwar', Muhammad Irshad2, Muhammad Javaid Asad ${ }^{3}$, \\ Hassan Ashfaq ${ }^{4}$ \\ ${ }^{1}$ Institute of Biochemistry and Biotechnology, University of Veterinary and Animal Sciences, Lahore, Pakistan \\ ${ }^{2}$ Department of Biochemistry and Molecular Biology, University of Gujrat, Gujrat, Pakistan \\ ${ }^{3}$ University Institute of Biochemistry and Biotechnology, PMAS Arid Agriculture University, Rawalpindi, Pakistan \\ ${ }^{4}$ Institute of Continuing Education \& Extension, University of Veterinary and Animal Sciences, Lahore, Pakistan \\ Email: *mirzaimran42@gmail.com
}

Received 11 April 2016; accepted 24 May 2016; published 27 May 2016

Copyright (C) 2016 by authors and Scientific Research Publishing Inc.

This work is licensed under the Creative Commons Attribution International License (CC BY).

http://creativecommons.org/licenses/by/4.0/

(c) (i) Open Access

\section{Abstract}

In energy deficient world, cellulases play a major role for the production of alternative energy resources utilizing lignocellulosic waste materials for bioethanol and biogas production. This study highlights fungal and bacterial strains for the production of cellulases and its industrial applications. Solid State Fermentation (SSF) is more suitable process for cellulase production as compared to submerge fermentation techniques. Fungal cellulosomes system for the production of cellulases is more desirable and resistant to harsh environmental conditions. Trichoderma species are considered as most suitable candidate for cellulase production and utilization in industry as compared to Aspergillus and Humicola species. However, genetically modified strains of Aspergillus have capability to produce cellulase in relatively higher amount. Bacterial cellulase are more resistant to alkaline and thermophile conditions and good candidate in laundries. Cellulases are used in variety of industries such as textile, detergents and laundries, food industry, paper and pulp industry and biofuel production. Thermally stable modified strains of fungi and bacteria are good future prospect for cellulase production.

\section{Keywords}

Cellulase, Bacteria, Lignocellulosic Wastes, Trichoderma, Solid State Fermentation

\footnotetext{
${ }^{*}$ Corresponding author.
}

How to cite this paper: Imran, M., Anwar, Z., Irshad, M., Asad, M.J. and Ashfaq, H. (2016) Cellulase Production from Species of Fungi and Bacteria from Agricultural Wastes and Its Utilization in Industry: A Review. Advances in Enzyme Research, 4, 44-55. http://dx.doi.org/10.4236/aer.2016.42005 


\section{Introduction}

This review highlights the potential utilization of fungal and bacterial species for the production of cellulases and their applications in diverse fields and industries. Cellulases are utilized in textile, food, medical, laundries, agriculture, textile, enhancement of animal feed digestibility and paper and pulp industry. Cellulase is a synergetic enzyme which is accustomed to split cellulose into glucose and/or different oligosaccharide compounds [1]. Cellulase enzymes may be divided into 3 types: endoglucanase (endo-1, 4- $\beta$-D-glucanase, EG, EC 3.2.1.4); cellobiohydrolase or exoglucanase (exo-1, 4- $\beta$-D-glucanase, CBH, EC 3.2.1.91) and $\beta$-glucosidase (1, 4- $\beta$-D-glucosidase, BG, EC 3.2.1.21) [2] [3], whereas EGs being the foremost economical enzyme [4].

Fungi are studied extensively among these organisms because of their elongated hyphae which produce mechanical pressure on the cellulose structure, inflicting them to supply massive amounts of cellulose. Subsequently, fungal strains have the capability to produce higher quantities of cellulases as compared to other organisms [5] [112].

Cellulases are required in potentially higher amount and its demands are expected to rise with passage of time [6]. Fungal cellulases have the potential to digest cellulose, hemicelluloses and lignin by secreting diverse set of hydrolytic and oxidative enzymes [7] [18]. Cellulases complex degrade cellulose in to fermentable sugars and play pivotal role in the conversion of biodegradable material in to ethanol. Cellulases have wide range of applications such as extraction of protein from soybeans and coconut, green tea compounds, unicellular vegetable production and formation of vinegar from citrus fruit pulp. Cellulases are widely used for the removal of seed coat of soybeans. It has potential use in the modification of glutinous rice, other food tissue and tensile strength of cellulosic material like paper quality improvement. Although, most important application of cellulases are the conversion of cellulosic wastes in to glucose but the microbial invasion make difficult the production of active extra cellular enzyme preparation [8] [15]. Lactose is amongst the well-known inducer of cellulase producer gene and is most economical additive in industry particularly in case of fermentation [9] [23]. Production of cellulase in microbial cultures is strictly concerned with growth and various factors affect the productivity [10] [22]. Various biomass inducing residues including; lignocellulosic material, paper waste, pulses cereals straw and bagasses have been widely used as carbon sources for commercial cellulase fermentations [11] [24]-[31]. Low yields over prolonged fermentation is the major limiting factor and for the production of cellulases; solid state fermentation (SSF) is gaining popularity being cost effective and equally useful for the bioconversion lignocellulosic material using cellulolytic microorganisms [12] [32]-[34].

\subsection{Fungal Cellusome System}

The adherence and digestion of lignocellulosic biomass by microbes is not such an easy understanding, in fact, it requires very specific molecular binding sites which are made to facilitate this purpose. These kind of specific molecular structures are known as cellulosomes and have a complex of varied enzymatic domains. The cellulosomes work in an efficient way in which they have proper mechanism of actions i.e., they attach to the biomass in the first step and in the next step; they degrade the biomass resulting in components which are further absorbed by the microbes to fulfill their food requirements [13].

As compared to bacterial cellulase systems, fungal cellulases are structurally less complicated. Fungal cellulases usually consist of 2 separate domains: cellulose binding module (CBM) and a catalytic domain (CD), which has a short polylinker region to its $\mathrm{N}$-terminal to join cellulose binding module (CBM) with it. The CBM has 35 amino acids, and the linker region has a plenty of Serine and Threonine. The major differentiating character between cellulosomes i.e., bound cellulase and free cellulase is that cellulosomes-cohesion has scaffolding and dockerin containing enzyme. Cellulose binding domains (CBMs) replaced by a dockerin in cellulosomal complex in free cellulase, and one scaffolding-born CBM directs the complete cellulosomes complex to cellulosic biomass [14] [19].

\subsection{Cellulase Bio-Production through Fermentation Using Agriculture Waste Materials}

Fermentation technique has been mostly used for the production of cellulases and $T$. reesai has been widely used in bioprocessing for cellulase production. Solid substrate fermentation could be preferred over liquid media in case of aerobic microorganisms [15].

The production of cellulase and pectinase using Aspergillus niger on corn cobs as a carbon source is examined. 
Different parameters are implied to check the optimization including temperature, $\mathrm{pH}$, biomass production and activity of enzyme. The maximum activity of cellulase $\left(1.9 \times 10^{-4} \mu \mathrm{g} / \mathrm{mL} / \mathrm{sec}\right)$ is produced on $4^{\text {th }}$ day while pectinase shows maximum activity $\left(1.5 \times 10^{-4} \mu \mathrm{g} / \mathrm{mL} / \mathrm{sec}\right)$ on $4^{\text {th }}$ and $5^{\text {th }}$ day. The temperature range of $50^{\circ} \mathrm{C}$ is found to be optimum for cellulase activity $\left(1.3 \times 10^{-4} \mu \mathrm{g} / \mathrm{mL} / \mathrm{sec}\right)$ while activity of pectinase $\left(1.6 \times 10^{-4}\right.$ $\mu \mathrm{g} / \mathrm{mL} / \mathrm{sec}$ ) shows $60^{\circ} \mathrm{C}$ as optimum temperature [16]-[19]. The $\mathrm{pH} 4$ is optimum for cellulase activity (2.70 $\times$ $\left.10^{-4} \mu \mathrm{g} / \mathrm{mL} / \mathrm{sec}\right)$ and $\mathrm{pH} 6$ is for activity of pectinase $\left(1.5 \times 10^{-4} \mu \mathrm{g} / \mathrm{mL} / \mathrm{sec}\right)$. The study reveals that Aspergillus niger has the capability of producing cellulase and pectinase using corn cobs under SSF [20].

Bagasse powder is used as a substrate for cellulase production employing novel thermo-stable yeast. Maximum cellulase yield obtains at $50^{\circ} \mathrm{C}$, medium of bagasse powder $4 \%(\mathrm{w} / \mathrm{v})+\left(\mathrm{NH}_{4}\right)_{2} \mathrm{SO}_{4}=0.1 \%(\mathrm{w} / \mathrm{v})$, $\mathrm{pH} 5.5$ and incubation time of 72 hours. Moreover the isolated yield is tolerant to wide ranges of substrate concentration, temperature and $\mathrm{pH}$ expressing higher productivity of enzyme [21]. Additionally, C1 exo-gluconase and endo-gluconase using a crude lignocellulosic material are also produced and hence can even be used for ethanol production [21]. Solely, fungi naturally manufacture the require titers of cellulases needed for the entire saccharification (30 - 50 mg enzyme/g of crystalline cellulose) [6] [22]. Many cellulase producing fungi including Trichoderma, penicillium, Botrytis neurospora [7] [23] genra Aspergilli [8] [24] Aspergillus niger and Aspergillus terreus, Rhizopus stolonifer [9] [25], Fusarium oxysporum [10] [26] are suitable for bioprocessing.

Solid state fermentation is the cheapest way of cellulase production from agro industrial wastes [11] [27]. Interestingly, recent studies report that SSF provides an additional adequate environment for fungi [12] [28]-[30] for various enzymes production. SSF commercialization has been used for production of enzymes ( $\sim 3.5$ billion tons per year). The advantage of exploiting SSF to attain the low cost fermentation system needed and the likelihood of getting it administrated on farms [13] [31]. Moreover, it is environmentally favorable, low energy demanding, inhibiting waste water release and economically feasible [14] [32]. The roles of Cellulases are inevitable in paper, pulp and textile industry of the world. Cellulose has a higher level of crystallinity and thus becomes difficult to be broken down into sub particles. To overcome this problem, Cellulolytic enzymes are used synergistically because the combination of cellulases expresses much more activities than the activity of individual cellulases. The action of these enzymes has been more elaborately explained by a most common and most accepted endo-exo energy model. This model suggests that there is proper mechanism of action employ by such enzymes in which endo-glucanases attack on random sites of the lignocellulosic chains exposing some new sites for cellobiohydrolases to attack. Cellobiohydrolases further performs its function as exoenzymes liberating two main products; one of the products is cellobiose which is the major product of this degradation process. On the other hand, $\beta$-glucosidases, which arenot considered legitimate cellulases, play a vital role within the breakdown of cellobiose and some other short oligosaccharides to final product is glucose [16] [33]. Cellulase activity is described as the capability of cellulase to digest crystalline cellulose extensively [17] [34].

Aspergillus terreus ion for cellulase production using rice straw as a substrate under solid state fermentation is reported and Response surface methodology implicating Box-Behnken-design apply to optimize temperature and $\mathrm{pH}$. The filter paper activity which is predicted under optimized conditions is $9.73 \mathrm{U} / \mathrm{g}$ and the approved activity is $10.96 \mathrm{U} / \mathrm{g}$. The study shows the use of pretreated rice straw with mild alkali to produce fermentable sugars with $74.19 \%$ adequacy [35].

Rice grass (Spartina spp.) use lignocellulosic material by implicating Aspergillus species under solid state fermentation process. The study reveals the efficacy of using rice grass (Spartina sp.) as the major substrate for yielding cellulase through a novel isolated strain of Aspergillus sp. (SEMCC-3.248) in solid-state fermentation. The parameters which are optimized for cellulase production, are rice grass $2.5 \mathrm{~g}, 1.5 \mathrm{~g}$ of wheat bran, $4 \mathrm{~mL}$ of nutrient medium $\left(\left(\mathrm{NH}_{4}\right)_{2} \mathrm{SO}_{4} 14 \mathrm{~g} / \mathrm{L}, \mathrm{CaCl}_{2} 4 \mathrm{~g} / \mathrm{L}, \mathrm{KH}_{2} \mathrm{PO}_{4} 2 \mathrm{~g} / \mathrm{L}\right.$, soluble starch $2.62 \mathrm{~g} / \mathrm{L}, \mathrm{MgSO} 4.7 \mathrm{H} 2 \mathrm{O} 0.2 \mathrm{~g} / \mathrm{L}$ and peptone $1.51 \mathrm{~g} / \mathrm{L}$ ), $1 \mathrm{~mL}$ of inoculum, moisture level $70 \%$, $\mathrm{pH} 5.0$, temperature $32^{\circ} \mathrm{C}$ and 5 days of incubation period. Following these optimum conditions, the total cellulase activity is $1.14 \mathrm{FPIU} / \mathrm{gds}$ [36].

Aspergillus niger HQ-1 is studied for cultivation and optimization using solid state fermentation process. Plackett-Burman design (PBD) is used to identify optimum incubation temperature, moisture content and culture $\mathrm{pH}$ for cellulase activity. The optimal regions containing three significant factors, is determined. Furthermore, response surface analysis and Box-Behnken design (BBD) are employed to find interactive effect between the three variables on the activity of cellulases. The optimum conditions are expressed to be temperature $33.5^{\circ} \mathrm{C}$ $33.7^{\circ} \mathrm{C}$, moisture level $70.3 \%-70.6 \%$ and $\mathrm{pH} 4.626$ - 4.662. Moreover, the activity of cellulase or hydrolysis of chitosan is high at $50^{\circ} \mathrm{C}$ and $\mathrm{pH}$ 5.6. This cellulase hydrolyzing activity is further improved by some metal ions $\mathrm{Mg}^{2+}, \mathrm{Mn}^{2+}, \mathrm{K}^{+}$and $\mathrm{Ca}^{2+}$ while is inhibited by $\mathrm{Ba}^{2+}, \mathrm{Zn}^{2+}, \mathrm{Co}^{2+}, \mathrm{Cu}^{2+}, \mathrm{Fe}^{3+}$ and $\mathrm{Ag}^{+}[37]$. 
Corn cobs are used for the production of cellulase enzyme using Alternaria alternata through solid state fermentation. Different optimizing parameters are implied to check the maximum yield of cellulase including incubation period $\left(1-7\right.$ days), $\mathrm{pH}\left(3.0\right.$ - 9.0) and temperature $\left(25^{\circ} \mathrm{C}-40^{\circ} \mathrm{C}\right)$. The optimal cultural conditions are like incubation period of 96 hours, $\mathrm{pH} 6.0$ and incubation temperature as $35^{\circ} \mathrm{C}$ expressing cellulase activity as $15.06 \mu \mathrm{g} / \mathrm{mL}, 26.4106 \mu \mathrm{g} / \mathrm{mL}$ and $31.2406 \mu \mathrm{g} / \mathrm{mL}$ respectively [38].

Eichhornia crassipes (water hyacinth) is used for cellulase production and the growth medium is enriched with water hyacinth mixture in ratio 1:05 (V/V) as energy source. Maximum cellulase is produced after incubation time of 6 days, temperature $30^{\circ} \mathrm{C}, 150 \mathrm{rpm}$ shaking speed at $\mathrm{pH}$ 5.0. Cellulases show maximum activity at optimum conditions including $40^{\circ} \mathrm{C}$ temperature and $\mathrm{pH}$ 5.0. Vmax and $\mathrm{Km}$ are observed to be $58.3 \mu \mathrm{mol} /$ $\mathrm{mL} / \mathrm{min}$ and $4.7 \mathrm{mg} / \mathrm{mL}$ respectively [39].

Solid state fermentation methodology is employed for endo-cellulases production of by Aspergillus japonicus C03. The temperature for maximum production is observed to be $50^{\circ} \mathrm{C}-55^{\circ} \mathrm{C}$ for cellulase production with the optimum $\mathrm{pH}$ of 4.0. Moreover, this enzyme is capable to bear the $\mathrm{pH}$ change of 4.0 - 7.0. It is also observed that Manganese and Copper enhanced the cellulase activity up to 64\% [40].

Soybean hulls are used to yield cellulolytic enzymes under solid state fermentation by Aspergillus oryzae and Trichoderma reesei cultures. It is observed that crystallinity is extremely increased by mild acid, alkali and steam pretreatments. The steam pretreated hulls is first inoculated with $T$. reesei and shows more cellulase activities (4 filter paper units (FPU)/g-ds, $45 \mathrm{IU} / \mathrm{g}$-ds endo-cellulase and $0.6 \mathrm{IU} / \mathrm{g}$-ds $\beta$-glucosidase) than untreated soybean hulls ( $0.75 \mathrm{FPU} / \mathrm{g}$-ds, $7.29 \mathrm{IU} / \mathrm{g}$-ds endocellulase and $0.06 \mathrm{IU} / \mathrm{g}$-ds $\beta$-glucosidase). In case of $A$. oryza, the pretreated hulls produce more endo-cellulases (47.10 IU/g-ds) than the untreated hulls (30.82 IU/g-ds). The work shows an interrelationship between enzymatic production and physiochemical characteristics [11] [41].

Castor bean is used as a substrate for cellulase production using Aspergillus japonicus URM5620 under solid state fermentation. A full factorial design $\left(2^{4}\right)$ is used to study the effects of different parameters like substrate concentration, $\mathrm{pH}$, moisture level, incubation period and temperature on enzyme yield. The optimum conditions are observed to be substrate concentration $5.0 \mathrm{~g}$, pH 6.0, moisture level 15\%, $120 \mathrm{~h}$ of incubation period and $25^{\circ} \mathrm{C}$ temperature. The optimization processes describes clearly the impact on enzyme production [41].

Some mutant strains of Aspergillus sp. SU14 for the production of cellulase are employed. Aspergillus sp. SU14 spores are frequently treated with ultraviolet irradiation, (Co60) $\gamma$-rays and N-methyl-N'-nitro-N-nitrosoguanidine. Aspergillus sp. SU14-M15 is a mutant strain with cellulase production 2.2-fold more than that of wild type. The optimum requirements for growth are examined to be medium containing wheat-bran enriched with urea $1 \%(\mathrm{w} / \mathrm{w})$, rice starch $1 \%(\mathrm{w} / \mathrm{w})$, Tween $800.05 \%(\mathrm{v} / \mathrm{w})$ and $\mathrm{MgCl}_{2} 2.5 \mathrm{mM}$, moisture $50 \%(\mathrm{v} / \mathrm{w}), \mathrm{pH}$ 3.5 with aeration area of $3 / 100$. When, $25 \%$ of 48 hours seeding culture is inoculated for 3 days at $35^{\circ} \mathrm{C}$, the resultant cellulase production is 8.5 times more than the conventional type of cellulase production [42].

Cellulase production on carboxymethyl cellulose by Aspergillus niger which is isolated from various sources of soil, is also studied with shaking flasks incubation with ambient temperature. All isolated strains show cellulase activity with the maximum yield at day $4(0.07162 \mathrm{IU} / \mathrm{mL} / \mathrm{min})$ produce by Aspergillus niger isolated by rice growing field whereas minimum activity $(0.02911 \mathrm{IU} / \mathrm{mL} / \mathrm{min})$ is by Aspergillus niger, isolated from street soil. The experiment reveals the cellulolytic capability of Aspergillus niger in almost all soil environments. Moreover, the results display that this robust strain can be isolated from rice growing fields for the production of commercial cellulase [43].

\section{Cellulase Producing Organisms}

Cellulolytic microorganisms mostly degrade carbohydrates and cannot utilize lipids and proteins as source of energy for metabolism and growth [44]. Among them, most important microorganisms are bacteria, cytophaga, cellulomonas can degrade carbohydrates other than cellulose [45] [46]. Anaerobic microbial species have limited cellulolytic activity restricted to cellulose and its hydrolytic products [15] [47].

Trichoderma reesai is the most widely studied fungus and has ability to convert desired as well as native cellulose to glucose. Among most widely studied organisms having notably high cellulolytic activity, include various fungal species like Humicola, Trichoderma, Penicillium and Aspergillus. Some bacterial species include; Pseudomonas, Bacilli, Actinomycetes, streptomycetes, Cellumonas, Streptomyces and Actinomucor [48]-[50]. Because of the ability of fungi to consume cellulose for energy consumption, only certain species could be used practically for cellulose hydrolysis. Despite of T. reesai, other fungal species include Aspergillus, Penicillium 
and Humicola have practical implementation to produce high yields of cellulases [51]-[53].

Certain aerobic bacterial species such as Cytophaga, Cellumonas and Cellovibrio have ability to degrade cellulose in pure culture [44] [54]. The most accepted commercially applicable microbes are A. niger recombinant, T. reesai, H. insolens, Thermomonasporafusa, Bacillus species and some other organisms (Table 1).

Table 1. Microorganisms used in cellulase production from microorganisms.

\begin{tabular}{|c|c|c|c|}
\hline Group & Genus & Species & References \\
\hline \multirow{7}{*}{ Bacteria } & Bacillus & Bacillus species & {$[54]$} \\
\hline & Acidothermus & A. Cellulyticus & {$[55]$} \\
\hline & Pseudomonas & P. cellulosa & {$[56]$} \\
\hline & Ruminococcus & R. albus & [57] \\
\hline & Clostridium & C. thermocellum & [58] \\
\hline & Clostridium & C. acetobutylium & [59] \\
\hline & Rodothermus & R. marinus & {$[60]$} \\
\hline \multirow{21}{*}{ Fungi } & Fusarium & F. solani & [61] \\
\hline & Aspergillus & A. niger & [53] [62] \\
\hline & Aspergillus & A. oryjae (recombinant) & [62] \\
\hline & Aspergillus & A. fumigatus & [63] \\
\hline & Aspergillus & A. acculeatus & [64] \\
\hline & Aspergillus & A. nidulans & [65] \\
\hline & Melanocarpus & M. albomyces & {$[66]$} \\
\hline & Humicola & H. grisea & [67] \\
\hline & Humicola & H. insolens & [49] [67] \\
\hline & Trichderma & T. reesai & [68] \\
\hline & Trichderma & T. koningii & [69] \\
\hline & Trichderma & T. viride & [64] [69] \\
\hline & Trichderma & T. harjianum & [70] \\
\hline & Trichderma & T. branchiatum & [71] \\
\hline & Sclerotium & S. rolfsii & [72] \\
\hline & Acremonium & A. Cellulyticus & [73] \\
\hline & Fusarium & F. solani & [74] \\
\hline & Sporotrichum & S. cellulophilum & [75] \\
\hline & Irpex & I. lacteus & [63] [75] \\
\hline & Penicillium & P.fumiculosum & [76] \\
\hline & Talaromyces & T. emersonii & [77] \\
\hline \multirow{7}{*}{ Actinomycetes } & Streptomyces & S. lividans & [78] \\
\hline & Streptomyces & S. drozdowiejii & [79] \\
\hline & Cellulomonas & C. uda & [80] \\
\hline & Cellulomonas & C. fimi & [81] \\
\hline & Cellulomonas & C. bioajotea & [46] [81] \\
\hline & Thermonospora & T. curvata & [82] \\
\hline & Thermonospora & T. fusca & [83] \\
\hline
\end{tabular}




\section{Cellulases Applications}

For the past few decades, cellulases has been widely studied for their importance in the conversion of biomass and other cellulosic materials which are otherwise consider as waste material. This is an important research tool in paper industry, textile industry, bio-fuel as renewable energy source, animal feed and detergents.

\subsection{Textile Industry}

Cellulases are amongst the most important group of enzyme in industry [84] and they have been employed to reduce the faded look and protruding fibers in fabrics and garments and to give them softness. Before that, pumice stone was used traditionally for this purpose [24] [85]-[87].

Cellulases from $H$. insolens are frequently used in bio-stoning along with proteases and trichoderma [88]. Cellulases give better finish and digest small fibers that cause roughness of the fabrics [70] [89]. They have been employed for defibrillation and softening of fabrics [89]. Cellulases are good localizing agents and are used to eliminate color variation of fibers [89] [90].

\subsection{Detergents and Laundries}

Cellulase CBH I and EG III have excellent cleansing properties and are used in textile cleaning. It has been reported that $T$. reesai producing EG III variants are suitable for the modification detergents. Similarly, $T$. harzianum and T. viride are also used as naturally producing sources of cellulases like A. niger [91] [111].

Cellulase production from Humicola species (H. grisea and $H$. insolens) is effective under mild alkaline conditions and at elevated temperatures. So, they are mostly used as additives in detergents and washing powders [92] [93]. Cellulases are added to detergents for the breakdown of hydrogen bonding under harsh environmental conditions such as alkaline or thermophile conditions [94] [111].

\subsection{In Food Industry}

Cellulases are employed in food industry to extract and clarify olive oil, fruit and vegetable juices, in the production purposes and fruit nectars [70] [94]. In brewing industry, glucanases are used as additives for the improvement of malting of barley. Decent color extraction and maceration could be achieved using glucanase and hemicellulose [70] [94]. Carotenoids, which have been used as food coloring agents can be extracted through cellulases [94]. Cellulases along with pectinases and hemicellulases have been used to modify nutritive quality of forages [95]. Digestibility and performances of animal feed has been reported to improve using cellulases [96]. Bedford et al. [97] reported that better digestibility and feed conversion ratio of cereal feed could be achieved through the addition of Trichoderma cellulases [97] [111].

\subsection{In Paper and Pulp Industry}

In paper and pulp industry, hemicellulases and cellulases have been used to modify the biochemical pulping of coarse pulp and to improve strengthening [97] [98]. These are equally useful for the depolarization of recycled pulp and for the efficiency improvement and drainage of paper mills [99] [100]. Cellulases have been employed to remove toners and coatings from paper [101] [102]. Microbial cellulases have also been used for the characterization of fiber pulp. Manufacturing of biodegradable cardboard can be easily done using cellulases [103] and also used to improve the soft texture of paper, manufacturing of sanitary paper and paper towels [104]-[106].

\subsection{Biofuel Production}

Production of biofuel is one of the most recently investigated applications of cellulases in the bioconversion of lignocellulosic wastes. Although, abundant cellulosic residues are available but major disadvantage of this biodegradation is cost effectiveness of the process. Cellulases have ability to convert lignocellulosic material into fermentable sugars like glucose, maltose, used as substrates to form bioethanol and other products. Certain microorganisms have been reported which have ability of direct conversion of biomass to various alcohols [107]-[109], but they are not used as efficient source commercially. This technique involves multistep process to convert lignocellulosic material into bioethanol. In the pretreatment process, fraction of hemicellulose and lignin is improved for further processing. Then the residues are hydrolyzed at $50^{\circ} \mathrm{C}$ to produce fermentable sugars and 
in the final step, microorganisms have been employed to convert cellulosic wastes into alcohol [110] [111].

\section{Conclusion}

Biotechnological applications of cellulases make future prospect for the hyper-production of cellulases by genetically modifying fungal and bacterial strains. In future, thermo-stable, alkaline resistant cellulases are made for applications in industries to attain high degradable yield.

\section{Conflict of Interest}

Authors have no conflict of interest with any scientist or department.

\section{References}

[1] Chellapandi, P. and Jani, H.M. (2008) Production of Endoglucanase by the Native Strains of Strptomyces Isolates in Submerged Fermentation. Brazilian Journal of Microbiology, 39, 122-127. http://dx.doi.org/10.1590/S1517-83822008000100026

[2] Gao, J., Weng, H., Zhu, D., Yuan, M., Guan, F. and Xi, Y. (2008) Production and Characterization of Cellulolytic Enzymes from the Thermoacidophilic Fungal Aspergillus terreus M11 under Solid-State Cultivation of Corn Stover. Bioresource Technology, 99, 7623-7629. http://dx.doi.org/10.1016/j.biortech.2008.02.005

[3] Kim, S. J., Lee, C.M., Han, B.R., Kim, M.Y., Yeo, Y.S., Yoon, S. H., Koo, B.S. and Jun, H.K. (2008) Characterization of a Gene Encoding Cellulase from Uncultured Soil Bacteria. FEMS Microbiology Letters, 282, 44-51. http://dx.doi.org/10.1111/j.1574-6968.2008.01097.x

[4] Henriksson, G., Nutt, A., Henriksson, H., Pettersson, B., Ståhlberg, J., Johansson, G. and Pettersson, G. (1999) Endoglucanase 28 (Cel12A), a New Phanerochaete Chrysosporium Cellulase. European Journal of Biochemistry, 259, 88-95. http://dx.doi.org/10.1046/j.1432-1327.1999.00011.x

[5] Amouri, B. and Gargouri, A. (2006) Characterization of a Novel $\beta$-Glucosidase from a Stachybotrys Strain. Biochemical Engineering Journal, 32, 191-197. http://dx.doi.org/10.1016/j.bej.2006.09.022

[6] Amore, A., Pepe, O., Ventorino, V., Birolo, L. Giangrande, C. and Faraco, V. (2012) Cloning and Recombinant Expression of a Cellulase from the Cellulolytic Strain Streptomyces sp. G12 Isolated from Compost. Microbial Cell Factories, 11, 164. http://dx.doi.org/10.1186/1475-2859-11-164

[7] Pandey, A., Selvakumar, P., Soccol, C.R. and Nigam, P. (1999) Solid State Fermentation for the Production of Industrial Enzymes. Current Science, 77, 149-162.

[8] Ali, U.F. and El-Dein, H.S. (2008) Production and Partial Purification of Cellulase Complex by Aspergillus niger and Aspergillus nidulans Grown on Water Hyacinth Blend. Journal of Applied Science Research, 4, 875-891.

[9] Pothiraj, C., Balaji, P. and Eyini, M. (2006) Enhanced Production of Cellulases by Various Fungal Cultures in Solid State Fermentation of Cassava Waste. African Journal of Biotechnology, 5, 1882-1885.

[10] Ramanathan, G., Banupriya, S. and Abirami, D. (2010) Production and Optimization of Cellulase from Fusarium oxysporum. Journal of Scientific and Industrial Research, 69, 454-459.

[11] Brijwani, K. and Vadlani, P.V. (2011) Cellulolytic Enzymes Production via Solid State Fermentation: Effect of Pretreatment Methods on Physiochemical Characteristics of Substrate. Enzyme Research, 2011, Article ID: 860134.

[12] Babitha, S., Soccol, C.R. and Pandey, A. (2006) Solid State Fermentation for the Production of Monascus Pigments from Jackfruit Seed. Bioresource Technology, 98, 1554-1560. http://dx.doi.org/10.1016/j.biortech.2006.06.005

[13] Graminha, E.B.N., Gonçalves, A.Z.L., Pirota, R.D.P.B., Balsalobre, M.A.A., Da Silva, R. and Gomes, E. (2008) Enzyme Production by Solid-State Fermentation: Application to Animal Nutrition. Animal Feed Science Technology, 144, 1-22. http://dx.doi.org/10.1016/j.anifeedsci.2007.09.029

[14] Pandey, A. (2003) Solid-State Fermentation. Biochemical Engineering Journal, 13, 81-84. http://dx.doi.org/10.1016/S1369-703X(02)00121-3

[15] Thurston, B., Dawson, K.A. and Strobel, H.J. (1993) Cellobiose versus Glucose Utilization by the Ruminal Bacterium Ruminococcus albus. Applied Environment Microbiology, 59, 2631-2637.

[16] Kaushal, R., Sharma, N. and Tandon, D. (2012) Cellulase and Xylanase Production by Co-Culture of Aspergillus niger and Fusarium oxysporum Utilizing Forest Waste. Turkish Journal of Biochemistry, 37, 35-41. http://dx.doi.org/10.5505/tjb.2012.43434

[17] Johnson, E.A., Sakojoh, M., Halliwell, G., Madia, A. and Demain, A.L. (1982) Saccharification of Complex Cellulosic Substrates by the Cellulase System from Clostridium thermocellum. Applied and Environmental Microbiology, 43, $1125-1132$. 
[18] Fatma, H., El-Zaher, A. and Fadel, M. (2010) Production of Bioethanol via Enzymatic Saccharification of Rice Straw by Cellulase Produced by Trichoderma reesei under Solid State Fermentation. New York Science Journal, 3, 72-78.

[19] Kuhad, R.C., Gupta, R. and Singh, A. (2011) Microbial Cellulases and Their Industrial Applications. Enzyme Research, 2011, Article ID: 280696. http://dx.doi.org/10.4061/2011/280696

[20] Oyeleke, S.B., Oyewole, O.A., Egwim, E.C., Dauda, B.E.N. and Ibeh, E.N. (2012) Cellulase and Pectinase Production Potentials of Aspergillus niger Isolated From Corn Cob. Bayero Journal of Pure and Applied Sciences, 5, 78-83. http://dx.doi.org/10.4314/bajopas.v5i1.15

[21] Rai, P., Tiwari, S. and Gaur, R. (2012) Optimization of Process Parameters for Cellulase Production by Novel Thermotolerant Yeast. BioResources, 7, 5401-5414. http://dx.doi.org/10.15376/biores.7.4.5401-5414

[22] Tholudur, A., Ramirez, W.F. and McMillan, J.D. (1999) Mathematical Modeling and Optimization of Cellulase Protein Production Using Trichoderma reesei RL-P37. Biotechnology and Bioengineering, 66, 1-16. http://dx.doi.org/10.1002/(SICI)1097-0290(1999)66:1<1::AID-BIT1>3.0.CO;2-K

[23] Aro, N., Pakula, T. and Penttilä, M. (2005) Transcriptional Regulation of Plant Cell Wall Degradation by Filamentous Fungi. FEMS Microbiology Revolution, 29, 719-739. http://dx.doi.org/10.1016/j.femsre.2004.11.006

[24] Belghith, H., Ellouz-Chaabouni, S. and Gargouri, A. (2001) Stabilization of Penicillium occitanis Cellulases by Spray Drying in Presence of Maltodextrin. Enzyme and Microbial Technology, 28, 253-258. http://dx.doi.org/10.1016/S0141-0229(00)00322-7

[25] Reczey, K., Szengyel, Z., Eklund, R. and Zacchi, G. (1996) Cellulase Production by T. reesei. Bioresource Technology, 57, 25-30. http://dx.doi.org/10.1016/0960-8524(96)00038-7

[26] Heck, J.X., Hertz, P.F. and Ayub, M.A.Z. (2002) Cellulase and Xylanase Production by Isolated Amazon bacillus Strains Using Soybean Industrial Residue Based Solid-State Cultivation. Brazilian Journal of Microbiology, 33, 213218. http://dx.doi.org/10.1590/S1517-83822002000300005

[27] Romero, M.D., Aguado, J., Gonzalez, L. and Ladero, M. (1999) Cellulase Production by Neurospora crassa on Wheat Straw. Enzyme and Microbial Technology, 25, 244-250. http://dx.doi.org/10.1016/S0141-0229(99)00035-6

[28] Szijártó, N., Faigl, Z., Réczey, K., Mézes, M. and Bersényi, A. (2004) Cellulase Fermentation on a Novel Substrate (Waste Cardboard) and Subsequent Utilization of Home-Produced Cellulase and Commercial Amylase in a Rabbit Feeding Trial. Industrial Crops and Products, 20, 49-57. http://dx.doi.org/10.1016/j.indcrop.2003.12.012

[29] Shen, X. and Xia, L. (2004) Production and Immobilization of Cellobiase from Aspergillus niger ZU-07. Process Biochemistry, 39, 1363-1367. http://dx.doi.org/10.1016/S0032-9592(03)00264-4

[30] Adsul, M.G., Ghule, J.E., Singh, R., Shaikh, H., Bastawdea, K.B., Gokhale, D.V. and Varma, A.J. (2004) Polysaccharides from Bagasse: Applications in Cellulase and Xylanase Production. Carbohydrate Polymers, 57, 67-72. http://dx.doi.org/10.1016/j.carbpol.2004.04.001

[31] Wen, Z., Liao, W. and Chen, S. (2005) Production of Cellulase/ $\beta$-Glucosidase by the Mixed Fungi Culture Trichoderma reesei and Aspergillus phoenicis on Dairy Manure. Process Biochemistry, 40, 3087-3094. http://dx.doi.org/10.1016/j.procbio.2005.03.044

[32] Pandey, A. (1992) Recent Process Developments in Solid-State Fermentation. Process Biochemistry, 27, 109-117. http://dx.doi.org/10.1016/0032-9592(92)80017-W

[33] Pandey, A., Soccol, C.R. and Mitchell, D. (2000) New Developments in Solid-State Fermentation: I-Bioprocesses and Products. Process Biochemistry, 35, 1153-1169. http://dx.doi.org/10.1016/S0032-9592(00)00152-7

[34] Pandey, A., Soccol, C.A., Rodriguez-Leon, J.A. and Nigam, P. (2001) Solid-State Fermentation in Biotechnology: Fundamentals and Applications. Asiatech Publishers Inc., New Delhi, 1-221.

[35] Narra, M., Dixit, G., Divecha, J., Madamwar, D. and Shah, A.R. (2012) Production of Cellulases by Solid State Fermentation with Aspergillus terreus and Enzymatic Hydrolysis of Mild Alkali-Treated Rice Straw. Bioresource Technology, 121, 355-361. http://dx.doi.org/10.1016/j.biortech.2012.05.140

[36] Liang, X., Huang, Y., Hua, D., Zhang, J., Xu, H., Li, Y. and Zhang, X. (2012) Cellulase Production by Aspergillus sp. on Rice Grass (Spartina spp.) under Solid-State Fermentation. African Journal of Microbiology Research, 6, 67856792.

[37] Zhang, J., Tang, M. and Viikari, L. (2012) Xylans Inhibit Enzymatic Hydrolysis of Lignocellulosic Materials by Cellulases. Bioresource Technology, 121, 8-12. http://dx.doi.org/10.1016/j.biortech.2012.07.010

[38] Goshadrou, A., Karimi, K. and Taherzadeh, M.J. (2011) Bioethanol Production from Sweet Sorghum Bagasse by Mucor hiemalis. Industrial Crops and Products, 34, 1219-1225. http://dx.doi.org/10.1016/j.indcrop.2011.04.018

[39] Sachin, T., Vishal, G., Sandeep, C., Rohan, I., Ajinkya, K., Sachin, M. and Meena, P. (2011) Production and Characterization of Cellulase by Local Fungal Isolate of India Using Water Hyacinth as Carbon Source and Reuse of Fungal Biomass for Dye Degradation. International Journal of Engineering Science and Technology, 3, 3236-3241. 
[40] Facchini, F.D., Vici, A.C., Reis, V.R., Jorge, J.A., Terenzi, H.F., Reis, R.A. and de Moraes Polizeli, L. (2011) Production of Fibrolytic Enzymes by Aspergillus japonicus $\mathrm{CO}_{3}$ Using Agro-Industrial Residues with Potential Application as Additives in Animal Feed. Bioprocess and Biosystems Engineering, 34, 347-355. http://dx.doi.org/10.1007/s00449-010-0477-8

[41] Herculano, P.N., Porto, T.S., Moreira, K.A., Pinto, G.A., Souza-Motta, C.M. and Porto, A.L. (2011) Cellulase Production by Aspergillus japonicas URM5620 Using Waste from Caster Bean (Ricinus communis L.) under Solid-State Fermentation. Applied Biochemistry and Biotechnology, 165, 1057-1067. http://dx.doi.org/10.1007/s12010-011-9321-0

[42] Vu, V.H., Pham, T.A. and Kim, K. (2011) Improvement of Fungal Cellulase Production by Mutation and Optimization of Solid State Fermentation. Mycobiology, 39, 20-25. http://dx.doi.org/10.4489/MYCO.2011.39.1.020

[43] Damisa, D., Ameh, J.B. and Egbe, N.E.L. (2011) Cellulase Production by Native Aspergillus niger Obtained from Soil Environments. Fermentation Technology and Bioengineering, 1, 62-70.

[44] Lynd, L.R., Weimer, P.J., van Zyl, W.H. and Pretorious, I.S. (2002) Microbial Cellulase Utilization: Fundamentals and Biotechnology. Microbiology and Molecular Biology Revolution, 66, 506-577. http://dx.doi.org/10.1128/MMBR.66.3.506-577.2002

[45] Poulsen, O.M. and Petersen, L.W. (1988) Growth of Cellulomonas sp. ATCC 21399 on Different Polysaccharides as Sole Carbon Source Induction of Extracellular Enzymes. Applied Microbiology and Biotechnology, 29, 480-484. http://dx.doi.org/10.1007/BF00269072

[46] Rajoka, M.I. and Malik, K.A. (1997) Cellulase Production by Cellulomonas biazotea Cultured in Media Containing Different Cellulosic Substrates. Bioresource Technology, 59, 21-27. http://dx.doi.org/10.1016/S0960-8524(96)00136-8

[47] Ng, T.K. and Zeikus, J.G. (1982) Differential Metabolism of Cellobiose and Glucose by Clostridium thermocellum and Clostridium thermohydrosulfuricum. Journal of Bacteriology, 150, 1391-1399.

[48] Hayashida, S., Otta, K. and Mo, K. (1988) Cellulases of Humicola insolens and Humicola grisea. In: Wood, W.A. and Abelson, J.N., Eds., Methods in Enzymology, Vol. 160, Academic Press, New York, 323-332. http://dx.doi.org/10.1016/0076-6879(88)60134-0

[49] Schülein, M. (1997) Enzymatic Properties of Cellulases from Humicola insolens. Journal of Biotechnology, 57, 71-81. http://dx.doi.org/10.1016/S0168-1656(97)00090-4

[50] Chaabouni, S.E., Belguith, H., Hassairi, I., M’Rad, K. and Ellouz, R. (1995) Optimization of Cellulase Production by Penicillium occitanis. Applied Microbiology and Biotechnology, 43, 267-269. http://dx.doi.org/10.1007/BF00172822

[51] Jørgensen, H., Eriksson, T., Börjesson, J., Tjerneld, F. and Olsson, L. (2003) Purification and Characterization of Five Cellulases and One Xylanase from Penicillium brasilianum IBT 20888. Enzyme and Microbial Technology, 32, 851861. http://dx.doi.org/10.1016/S0141-0229(03)00056-5

[52] van-Den Broeck, H.C., De Graaff, L.H., Visser, J.V.O. and Albert, J.J. (2001) Fungal Cellulases. US Patent No. 6306635 (to Gist-Brocades BV, NL).

[53] Ong, L.G., Abd-Aziz, S., Noraini, S., Karim, M.I. and Hassan, M.A. (2004) Enzyme Production and Profile by Aspergillus niger during Solid Substrate Fermentation Using Palm Kernel Cake as Substrate. Applied Biochemistry and Biotechnology, 118, 73-79. http://dx.doi.org/10.1385/ABAB:118:1-3:073

[54] Mawadza, C., Hatti-Kaul, R., Zvauya, R. and Mattiasson, B. (2000) Purification and Characterization of Cellulases Produced by Two Bacillus Strains. Journal of Biotechnology, 83, 177-187. http://dx.doi.org/10.1016/S0168-1656(00)00305-9

[55] Tucker, M.P., Mohagheghi, M., Grohmann, K. and Himmel, M.E. (1989) Ultra-Thermostable Cellulases from Acidothermus cellulolyticus: Comparison of Temperature Optima with Previously Reported Cellulases. Nature Biotechnology, 7, 817-820. http://dx.doi.org/10.1038/nbt0889-817

[56] Yamane, K., Suzuki, H. and Nisizawa, K. (1970) Purification and Properties of Extracellular and Cell-Bound Cellulase Components of Pseudomonas fluorescens var. cellulosa. Journal of Biochemistry, 67, 19-35.

[57] Leatherwood, J.M. (1965) Cellulase from Ruminococcus albus and Mixed Rumen Microorganisms. Applied Microbiology, 13, 771-775.

[58] Weimer, P.J. and Zeikus, J.G. (1977) Fermentation of Cellulose and Cellobiose by Clostridium thermocellum in the Absence of Methanobacterium thermoautotrophicum. Applied and Environmental Microbiology, 33, 289-297.

[59] López-Contreras, A.M., Gabor, K., Martens, A.A., Renckens, B.A.M., Claassen, P.A.M., van der Oost, J. and de Vos, W.M. (2004) Substrate-Induced Production and Secretion of Cellulases by Clostridium acetobutylicum. Applied Environmental Microbiology, 70, 5238-5243. http://dx.doi.org/10.1128/aem.70.9.5238-5243.2004

[60] Hreggvidsson, G.O., Kaiste, E., Holst, O., Eggertsson, G., Palsdottir, A. and Kristjansson, A.J. (1996) An Extremely Thermostable Cellulase from the Thermophilic Eubacterium Rhodothermus marinus. Applied and Environmental Microbiology, 62, 3047-3049. 
[61] Wood, T.M. and McCrae, S.I. (1977) Cellulase from Fusarium solani: Purification and Properties of $\mathrm{C}_{1}$ Component. Carbohydrate Research, 57, 117-133. http://dx.doi.org/10.1016/s0008-6215(00)81925-4

[62] Takashima, S., Iikura, H., Nakamura, A., Hidaka, M., Masaki, H. and Uozumi, T. (1998) Overproduction of Recombinant Trichoderma reesei Cellulases by Aspergillus oryzae and Their Enzymatic Properties. Journal of Biotechnology, 65, 163-171. http://dx.doi.org/10.1016/S0168-1656(98)00084-4

[63] Ximenes, E.A., Felix, C.R. and Ulhoa, C.J. (1996) Production of Cellulases by Aspergillus fumigatus and Characterization of One $\beta$-Glucosidase. Current Microbiology, 32, 119-123. http://dx.doi.org/10.1007/s002849900021

[64] Khokhar, I., Haider, M.S., Mushtaq, S. and Mukhtar, I. (2012) Isolation and Screening of Highly Cellulolytic Filamentous Fungi. Journal of Applied Sciences and Environmental Management, 16, 223-226.

[65] Kwon, K.S., Kang, H.G. and Hah, Y.C. (1992) Purification and Characterization of Two Extracellular Beta-Glucosidases from Aspergillus nidulans. FEMS Microbiology Letters, 76, 149-153.

[66] Miettinen-Oinonen, A., Londesborough, J., Joutsjoki, V., Lantto, R. and Vehmaanpera, J. (2004) Three Cellulases from Melanocarpus albomyces for Textile Treatment at Neutral pH. Enzyme and Microbial Technology, 34, 332-341. http://dx.doi.org/10.1016/j.enzmictec.2003.11.011

[67] Takashima, S., Nakamura, A., Masaki, H. and Uozumi, T. (1966) Purification and Characterization of Cellulases from Humicola grisea. Bioscience, Biotechnology, and Biochemistry, 60, 77-82. http://dx.doi.org/10.1271/bbb.60.77

[68] Saloheimo, M., Lehtovaara, P., Penttilä, M., Teeri, T.T., Ståhlberg, J., Johansson, G., Pettersson, G., Claeyssens, M., Tomme, P. and Knowles, J.K.C. (1988) EGIII, a New Endoglucanase from Trichoderma reesei: The Characterization of Both Gene and Enzyme. Gene, 63, 11-21. http://dx.doi.org/10.1016/0378-1119(88)90541-0

[69] Wood, T.M. and Mccrae, S.I. (1982) Purification and Some Properties of the Extracellular $\beta$-D-Glucosidase of the Cellulolytic Fungus Trichoderma koningii. Microbiology, 128, 2973-2982. http://dx.doi.org/10.1099/00221287-128-12-2973

[70] Galante, Y.M., De Conti, A. and Monteverdi, R. (1998) Application of Trichoderma Enzymes in Textile Industry. In: Harman, G.F. and Kubicek, C.P., Eds., Trichoderma and Gliocladium. Vol. 2, Enzymes, Biological Control and Commercial Applications, Taylor and Francis, London, 311-326.

[71] Vargas, M. and Dussan, J. (2002) Biosafety of Native Strains of Trichoderma spp. Fungus Used for Microbial Control. Actual Biology, 24, 37-48.

[72] Sadana, J.C., Shewale, J.G. and Deshpande, M.V. (1979) Enhanced Cellulase Production by a Mutant of Sclerotium rolfsii. Applied and Environmental Microbiology, 38, 730-733.

[73] Fang, X., Yano, S., Inoue, H. and Sawayama, S. (2008) Strain Improvement of Acremonium cellulyticus for Cellulase Production by Mutation. Journal of Bioscience and Bioengineering, 107, 256-261. http://dx.doi.org/10.1016/j.jbiosc.2008.11.022

[74] Wood, T.M. (1971) The Cellulase of Fusariumsolani. Purification and Specificity of the $\beta$-(1 $\rightarrow 4)$-Glucanase and the $\beta$-d-Glucosidase Components. Biochemical Journal, 121, 353-362. http://dx.doi.org/10.1042/bj1210353

[75] Kim, J.H., Hosobuchi, M., Kishimoto, M., Seki, T., Yoshida, T., Taguchi, H. and Ryu, D.D. (1985) Cellulase Production by a Solid State Culture System. Biotechnology and Bioenergy, 27, 1445-1450.

[76] van Wyk, J.P.H. (1999) Saccharification of Paper Products by Cellulase from Penicillium funiculosum and Trichoderma reesei. Biomass and Bioenergy, 16, 239-242. http://dx.doi.org/10.1016/S0961-9534(98)00079-8

[77] Bengtsson, L., Johansson, B., Hackett, T.J., McHale, L. and McHale, A.P. (1995) Studies on the Biosorption of Uranium by Talaromyces emersonii CBS 814.70. Biomass. Applied Microbiology and Biotechnology, 42, 807-811. http://dx.doi.org/10.1007/BF00171965

[78] Theberge, M., Lacaze, P., Shareck, F., Morosoli, R. and Kluepfel, D. (1992) Purification and Characterization of an Endoglucanase from Streptomyces lividans 66 and DNA Sequence of the Gene. Applied and Environmental Microbiology, 58, 815-820.

[79] de Lima, A.L.G., do Nascimento, R.P., da Silva Bon, E.P. and Coelho, R.R.R. (2005) Streptomyces drozdowiczii Cellulase Production Using Agro-Industrial By-Products and Its Potential Use in the Detergent and Textile Industries. Enzyme and Microbial Technology, 37, 272-277. http://dx.doi.org/10.1016/j.enzmictec.2005.03.016

[80] Nakamura, K. and Kitamura, K. (1983) Purification and Some Properties of a Cellulase Active on Crystalline Cellulose from Cellulomonas uda. Journal of Fermentation Technology, 61, 379-382.

[81] Shen, H., Meinke, A., Tomme, P., Damude, H.G., Kwan, E., et al. (1996) Cellulomonas fimi Cellobiohydrolases. In: Saddler, J.N. and Penner, M.H., Eds., Enzymatic Degradation of Insoluble Carbohydrates, Oxford University Press, London, 174-196. http://dx.doi.org/10.1021/bk-1995-0618.ch012

[82] Stutzenberger, F.J. (1972) Cellulolytic Activity of Thermomonospora curvata: Nutritional Requirements for Cellulase Production. Applied Microbiology, 24, 77-82. 
[83] Wilson, D.B. (1988) Cellulases of Thermomonospora fusca. In: Abelson, J.A., et al., Methods in Enzymology: Biomass Part A: Cellulose and Hemicellulose (Biomass Vol. 160), Academic Press, San Diego, 314-323. http://dx.doi.org/10.1016/0076-6879(88)60133-9

[84] Xia, L. and Cen, P. (1999) Cellulase Production by Solid State Fermentation on Lignocellulosic Waste from the Xylose Industry. Process Biochemistry, 34, 909-912. http://dx.doi.org/10.1016/S0032-9592(99)00015-1

[85] Bhat, M.K. (2000) Cellulases and Related Enzymes in Biotechnology. Biotechnology Advances, 18, 355-383. http://dx.doi.org/10.1016/S0734-9750(00)00041-0

[86] Olson, L.A. and Stanley, P.M. (1991) Cellulase Compositions and Methods That Introduce Variations in Color Density into Cellulosic Fabrics, Particularly Indigo Dyed Denim. US Patent No. 5006126 (to Ecolab Inc., USA).

[87] Olson, L.A. (1990) Treatment of Denim with Cellulase to Produce a Stone Washed Appearance. US Patent No. 4912056 (to Ecolab Inc., USA).

[88] Cortez, J.M., Ellis, J. and Bishop, D.P. (2001) Cellulase Finishing of Woven, Cotton Fabrics in Jet, Winch Machines. Journal of Biotechnology, 89, 239-245. http://dx.doi.org/10.1016/S0168-1656(01)00307-8

[89] Kvietok, L.L., Trinh, T. and Hollingshead, J.A. (1995) Cellulase Fabric-Conditioning Compositions. US Patent No. 5445747

[90] Galante, Y.M. and Formantici, C. (2003) Enzyme Applications in Detergency and in Manufacturing Industries. Current Organic Chemistry, 7, 1399-1422. http://dx.doi.org/10.2174/1385272033486468

[91] Kottwitz, B. and Schambil, F. (2005) Cellulase and Cellulose Containing Detergents. US Patent No. 20050020472.

[92] Mitchinson, C. and Wendt, D.J. (2001) Variant EGIII-Like Cellulase Compositions. US Patent No. 6268328 (to Genencore International Inc.).

[93] Uhlig, H. (1998) Industrial Enzymes and Their Applications. John Wiley and Sons, Inc., New York, 435.

[94] Pajunen, E. (1986) Optimal Use of $\beta$-Glucanases in Wort Production. In: EBC-Symposium on Wort Production, Monograph XI, Maffliers, France, 137-148.

[95] Çinar, I. (2005) Effects of Cellulase and Pectinase Concentrations on the Colour Yield of Enzyme Extracted Plant Carotenoids. Process Biochemistry, 40, 945-949. http://dx.doi.org/10.1016/j.procbio.2004.02.022

[96] Kung Jr., L.J., Kreck, E.M., Tung, R.S., Hession, A.O., Sheperd, A.C., Cohen, M.A., Swain, H.E. and Leedle, J.A.Z. (1997) Effects of a Live Yeast Culture and Enzymes on in Vitro Ruminal Fermentation and Milk Production of Dairy Cows. Journal of Dairy Science, 80, 2045-2051. http://dx.doi.org/10.3168/jds.S0022-0302(97)76149-6

[97] Bedford, M.R., Morgan, A.J., Fowler, T., Clarkson, K.A., Ward, M.A., Collier, K.D. and Larenas, E.A. (2003) Enzyme Feed Additive and Animal Feed Including It. US Patent No. 6562340 (to Genencore International Inc., USA).

[98] Akhtar, M. (1994) Biochemical Biomechanical Pulping of Aspen Wood Chips with Three Strains of Ceriporiopsis subvermispora. Holzforschung, 48, 199-202. http://dx.doi.org/10.1515/hfsg.1994.48.3.199

[99] Pere, J., Siika-Aho, M., Buchert, J. and Viikari, L. (1995) Effects of Purified T. reesei Cellulases on the Fibre Properties of Kraft Pulp. Tappi Journal, 78, 71-78.

[100] Prasad, D.Y., Heitmann, J.A. and Joyce, T.W. (1992) Enzyme Deinking of Black and White Letterpress Printed Newsprint Waste. Progress in Paper Recycling, 1, 21-30.

[101] Pere, J., Paavilainen, L., Siika-Aho, M., Cheng, Z. and Viikari, L. (1996) Potential Use of Enzymes in Drainage Control of Nonwood Pulps. Proceedings of the 3rd International Non-Wood Fibre Pulping and Paper Making Conference, 2, 421-430.

[102] Franks, N.E., Bazewicz, S.E. and Holm, H.C. (1996) Use of Monocomponent Cellulase for Removing Inks, Coatings, and Toners from Printed Paper. US Patent No. 5525193 (to Novo Nordisk A/S, Denmark).

[103] Buchert, J., Oksanen, T., Pere, J., Siikaaho, M., Suurnakki, A. and Viikari, L. (1998) Applications of Trichoderma reesei Enzymes in the Pulp and Paper Industry. In: Harman, G.F. and Kubicek, C.P., Eds., Trichoderma and Gliocladium. Vol. 2, Enzymes, Biological Control and Commercial Applications, Taylor and Francis, London, 343-363.

[104] Salkinoja-Salonen, M. (1990) Method for Manufacturing Paper or Cardboard and Product Containing Cellulose. US Patent No. 4980023 (to Enso-Gutzeit Oy, Helsinki, FI).

[105] Hsu, J.C. and Lakhani, N.N. (2002) Method of Making Absorbent Tissue from Recycled Waste Paper. US Patent No. 6413363 (to Kimberly-Clark Worldwide, Inc., Wisconsin, USA).

[106] Sharyo, M., Sakaguchi, H., Ohishi, M., Takahashi, M., Kida, K., Tamagawa, H., Schulein, M. and Franks, N. (2002) Method of Making Sanitary Paper from Chemical Pulp Using a Single Component Cellulase That Does Not Contain Cellulose-Building Domain. US Patent No. 6468391 (to Novozymes A/S, Denmark).

[107] Martin, J.W. (1978) Method of Removing Paper Adhered to a Surface. US Patent No. 4092175 (William Zinnsserand Co., Inc., USA). 
[108] Deshpande, V., Keskar, S., Mishra, C. and Rao, M. (1986) Direct Conversion of Cellulose/Hemicellulose to Ethanol by Neurospora crassa. Enzyme and Microbial Technology, 8, 149-152. http://dx.doi.org/10.1016/0141-0229(86)90103-1

[109] Kundu, S., Ghose, T.K. and Mukhopadhyay, S.N. (1983) Bioconversion of Cellulose into Ethanol by Clostridium thermocellum —-Product Inhibition. Biotechnology and Bioengineering, 25, 1109-1126. http://dx.doi.org/10.1002/bit.260250418

[110] Rani, S.K., Swamy, M.V. and Seenayya, G. (1997) Increased Ethanol Production by Metabolic Modulation of Cellulose Fermentation in Clostridium thermocellum. Biotechnology Letters, 19, 819-823. http://dx.doi.org/10.1023/A:1018312931542

[111] Menedez, E., Garcia-Fraile, P. and Rivas, R. (2015) Biotechnological Applications of Bacterial Cellulases. AIMS Bioengineering, 2, 163-182. http://dx.doi.org/10.3934/bioeng.2015.3.163

[112] Gaur, R. and Tiwari, S. (2015) Isolation, Production, Purification and Characterization of an Organic-Solvent-Thermostable Alkalophilic Cellulase from Bacillus vallismortis RG-07. BMC Biotechnology, 15, 19. http://dx.doi.org/10.1186/s12896-015-0129-9 